\title{
Pelatihan Pengembangan LKPD Berbasis Keterampilan Proses Sains (KPS) Dan Penyusunan Instrumen Asesmen KPS Bagi Guru IPA
}

\author{
Dea Diella ${ }^{1}$, Ryan Ardiansyah ${ }^{2}$, Herni Yuniarti Suhendi ${ }^{3}$ \\ 1,2Pendidikan Biologi, Fakultas Keguruan dan Ilmu Pendidikan, Universitas Siliwangi \\ ${ }^{3}$ Pendidikan Fisika, Fakultas Tarbiyah dan Keguruan, Universitas Islam Negeri Sunan Gunung Djati \\ 11deadiella@unsil.ac.id \\ 2ryanardiansyah@unsil.ac.id \\ 3herni.suhendi@uinsgd.ac.id
}

\begin{abstract}
ABSTRAK
Tujuan dari diadakannya Pelatihan Pengembangan LKPD berbasis Keterampilan Proses Sains (KPS) dan Penyusunan Instrumen Asesmen KPS bagi guru IPA SMP adalah untuk melatihkan pembuatan lembar kegiatan peserta didik (LKPD), mengenalkan KPS dan mengintegrasikannya pada LKPD yang dibuat oleh guru-guru IPA. Selain itu, teknik pembuatan instrumen untuk mengases atau menilai KPS pun dilatihkan pada guru-guru IPA. Metode yang digunakan untuk mencapai tujuan kegiatan adalah pelatihan dan mini workshop. Pelatihan dilakukan di awal kegiatan sebagai pendahuluan yang kemudian akan dilanjutkan dengan kegiatan workshop penyusunan LKPD KPS dan instrumen (soal) penilaian KPS. Capaian atau hasil dari kegiatan dibahas secara deskriptif yang menampilkan profil kemampuan meyusun LKPD dan instrumen asesmen KPS. Hasil pelatihan menunjukkan bahwa kemampuan mengintegrasikan jenis KPS ke dalam LKPD adalah sebagai berikut (1) observasi 88.9\%; (2) klasifikasi 22.2\%;(3) interpretasi 100\%), (4) prediksi 55.5\%, (5)komunikasi $88.9 \%$; (6)merumuskan masalah $88.9 \%$; (7) hipotesis $100 \%$, (8) merencanakan percobaan $100 \%$, (9) menggunakan alat bahan 100\%; (10) menerapkan konsep 88.9\%. Untuk kemampuan menyusun instrumen asesmen KPS capaiannya lebih rendah yakni (1) observasi 44.4\%; (2) klasifikasi 44.4\%;(3) interpretasi 55.5\%), (4) prediksi 55.5\%, (5)komunikasi 55.5\%; (6)merumuskan masalah 55.5\%; (7) hipotesis $55.5 \%$, (8) merencanakan percobaan $66.7 \%$, (9) menggunakan alat bahan $66.7 \%$; (10) menerapkan konsep $66.7 \%$.
\end{abstract}

Kata kunci: $L K P D$, Keterampilan Proses Sains, Asesmen

\section{PENDAHULUAN}

Guru dalam menyiapkan proses pembelajaran tidak dapat terlepas dari beragam perangkat pembelajaran. Salah satu perangkat pembelajaran yakni Lembar Kegiatan Peserta Didik (LKPD) merupakan alat bantu dalam mengarahkan kegiatan belajar peserta didik. Komponen LKPD terdiri atas judul, alokasi waktu, tujuan pembelajaran, ringkasan materi esensial, dan prosedur kegiatan belajar yang harus dilakukan peserta didik. Umumnya guru menggunakan LKPD yang terdapat dalam buku belajar peserta didik. Dengan kata lain LKPD itu dibuat oleh orang lain. Sehingga guru kurang terampil dalam menyusun LKPD yang sesuai dengan kondisi dan kebutuhan peserta didiknya.

Berdasarkan permendikbud tahun 2016, Kurikulum 2013 hanya menerapkan pendekatan saintifik. Pendekatan ini ditandai dengan adanya proses saintifik atau ilmiah selama proses pembelajaran. Proses saintifik yang dimaksud tergambar dalam proses pembelajaran yang melibatkan kegiatan peserta didik berupa megobservasi, menanya, mengumpulkan data, mengasosiasi, menyimpulkan dan mengkomunikasin. Kegiatan saintifk tersebut berkaitan dengan keterampilan proses sains (KPS). Keterampilan yang dimaksud terdiri atas keterampilan observasi, klasifikasi, merumuskan pertanyaan, menyusun hipotesis, merencanakan percobaan, memilih alat bahan percobaan, menggunakan alat bahan, memprediksi, interpretasi, dan mengkomunkasikan (Tawil dan Liliasari, 2014).

Lembar kegiatan peserta didik (LKPD) yang diintegrasikan keterampilan proses sains (KPS) akan membantu peserta didik dalam meningkatkan pemahaman kognitif dan keterampilan sains. Sehingga proses pembelajaran sains akan sangat khas bila dibandingkan dengan bidang studi lainnya dan 
pendekatan saintifik akan terlaksana dengan sangat baik.

Selain dalam proses pembelajaran, KPS dapat diases melalui instrumen KPS. Jenis instrumen ini tidak sama dengan soal-soal tes pada umumnya karena yang diujikan adalah perihal keterampilan sains.

Keuntungan dari membuat LKPD sendiri oleh guru yang bersangkutan adalah mampu merencanakan dan melaksanakan proses pembelajaran yang efektif dan efisien bagi peserta didiknya. Hal ini dikarenakan, prosedur yang terdapat dalam LKPD akan sesuai dengan kondisi nyata di lingkungan sekolahnya. Keterampilan proses sains yang diintegrasikan dalam LKPD akan membantu peserta didik untuk selalu menggunakan keterampilan sains dalam mempelajari suatu konsep. Hal tersebut sejalan dengan hakekat sains yakni proses, produk (hasil), dan sikap. Sains tidak hanya dipelajari hasil-hasilnya (teori, hukum, prinsip dll) tetapi juga prosesnya yang melibatkan metode dan sikap ilmiah.

Survei kemampuan sains, matematika dan membaca yang secara berkala dilakukan oleh OECD (Organization for Economi Cooperation and Development) terhadap siswa usia 15 tahun, menunjukkan peringkat Indonesia yang mengkhawatirkan. Menyadarkan guru akan pentingnya melatihkan keterampilan proses sains diharapkan dapat meningkatkan pemahaman peserta didik tentang sains

Permasalah mitra yang teridentifikasi ketika observasi dan wawancara antara lain adalah : (1) Guru tidak terampil dalam menyusun lembar kegiatan peserta didik (LKPD) IPA. Umumnya mereka membuat LKPD berupa kumpulan soal atau pertanyaan yang cukup dijawab oleh peserta didik melalui kegiatan menyalin kalimat dari buku teks. LKPD yang digunakan rata-rata diambil dari buku teks (dibuat oleh orang lain) sehingga tidak semua LKPD akan membantu atau sesuai untuk peserta didiknya.(2) Guru IPA belum mampu mengembangkan keterampilan yang harus dimiliki oleh peserta didiknya untuk belajar IPA. Keterampilan yang dimaksud adalah keterampilan proses sains. Sehingga IPA dipelajari sebagai hapalan tanpa adanya pengembangan proses berpikir dan keterampilan yang sejalan dengan metode ilmiah. (3) Guru IPA masih mengandalkan soal tes kognitif sebagai satu-satunya instrumen untuk menilai mata pelajaran IPA.
Dengan permasalahan tersebut, maka kami sebagai pengusul bersama mitra memberikan pelatihan pengembangan Lembar Kegiatan Peserta Didik berbasis Keterampilan Proses Sains dan Penyusunan Instrumen Asesmen KPS sebagai upaya peningkatan kompetensi guru dalam melaksanakan pembelajaran IPA

\section{METODE KEGIATAN}

Partisipan dalam kegiatan pelatihan Pengembangan LKPD berbasis KPS dan Peyusunan Instrumen Asesmen KPS adalah guru IPA yang tergabung dalam MGMP IPA Kabupaten Tasikmalaya. Pelatihan dilaksanakan di SMPN 1 Singaparna pada tanggal 4 sampai 7 Agustus 2018.

Metode yang digunakan untuk mencapai tujuan pengabdian ini adalah metode pelatihan dan mini workshop. Pelatihan berupa penyajian materi terkait LKPD dan Keterampilan Proses Sains. Pengabdian dilanjut dengan workshop pembuatan LKPD berbasis KPS dan instrument KPS.

Kegiatan pelatihan dilaksanakan dengan tahapan sebagai berikut :

1. Pemaparan teori tentang LKPD dan Keterampilan Proses Sains (KPS)

2. Workshop penyusunan LKPD berbasis KPS

3. Pemaparan teori asesmen Keterampilan Proses Sains (KPS)

4. Workshop penyusunan instrument soal KPS beserta rubrik penilaiannya

\section{HASIL \& PEMBAHASAN}

Kegiatan pelatihan pengembangan LKPD berbasis KPS dan penyusunana instrumen KPS dikemas secara deduktif. Teori -teori disampaikan terlebih dahulu kemudian keesokan harinya dilakukan praktik pembuatan LKPD secara workshop. Demikian halnya dengan penyusunan instrument. Teori tentang asesmen KPS, syarat umum dan khusus soal KPS dan cara perumusan rubriknya disampaikan terlebih dahulu kemudian dilanjutkan dengan workshop penyusunan instrumennya. Selama proses workshop, guru bekerja secara berkelompok dan pekerjaannya senantiasa dimonitoring oleh narasumber. Di akhir sesi workshop, peserta mempresentasikan karnyanya (LKPD dan instrument) kemudian didiskusikan dan diverifikasi oleh narasumber.

Hasil Capaian kemampuan peserta pelatihan (guru IPA) dalam menyusun LKPD berbasis KPS dan instrumen asesmen KPS 
dapat dilihat pada grafik di bawah ini. Hasil pelatihan menunjukkan bahwa kemampuan mengintegrasikan jenis KPS ke dalam LKPD adalah sebagai berikut (1) observasi 88.9\%; (2) klasifikasi $22.2 \%$;(3) interpretasi 100\%), (4) prediksi $55.5 \%$, (5)komunikasi $88.9 \%$; (6)merumuskan masalah $88.9 \%$; (7) hipotesis $100 \%$, (8) merencanakan percobaan $100 \%$, (9) menggunakan alat bahan $100 \%$; (10) menerapkan konsep 88.9\%. Untuk kemampuan menyusun instrumen asesmen KPS capaiannya lebih rendah yakni (1) observasi $44.4 \%$; (2) klasifikasi $44.4 \%$;(3) interpretasi 55.5\%), (4) prediksi $55.5 \%$, (5)komunikasi $55.5 \%$; (6)merumuskan masalah 55.5\%; (7) hipotesis $55.5 \%$, (8) merencanakan percobaan $66.7 \%$, (9) menggunakan alat bahan $66.7 \%$; (10) menerapkan konsep $66.7 \%$. Berdasarkan data tersebut, kemampuan dalam menyusun LKPD berbasis KPS sudah cukup baik. Untuk KPS jenis klasifikasi prosentase peserta yang mampu mengintegrasikannya dalam LKPD sangat kecil karena berbenturan dengan karakteristik materinya. Tidak semua materi IPA mengandung konten yang tepat untuk proses klasifikasi. Untuk KPS jenis prediksi hampir sebagian peserta melakukan kesalahan dengan menyajikan data yang bersifat kualitatif sehingga tidak tepat dijadikan dasar untuk melakukan prediksi. Pengembangan LKPD berbasis KPS jarang dilakukan oleh guru karena fokus tujuan belajar masih didominasi oleh pengetahuan (konsep. Padahal dalam kerangka taksonomi Bloom (Anderson et al,2010) pengetahuan diklasifikasikan ke

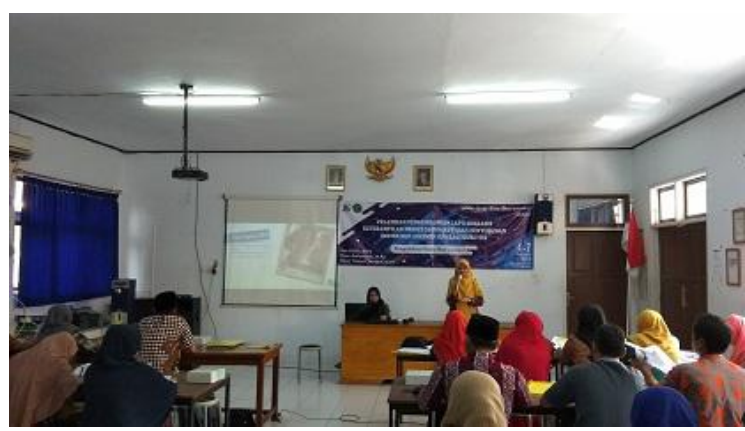

Gambar 1. Penyampaian materi tentang KPS dalam pengetahuan fakta,konseptual, prosedural , dan metakognitif. Pengetahuan prosedural akan menuntut peserta didik untuk terampil dalam menggunakan metode ilmiah yang menjadi dasar keterampilan proses sains (KPS). Sejalan dengan hal tersebut Gultepe (2016) menemukan fakta tentang persepsi guru terhadap KPS yang menunjukkan bahwa guru sulit melaksanakan KPS karena kurikulum (sistem pendidikan) berpusat pada hasil ujian sekolah (central-examination) sehingga materi sangat ketat disampaikan dengan penekanan pemahaman konsep.

Kemampuan menyusun instrumen asesmennya masih kurang pada beberapa jenis KPS. Umumnya mereka kesulitan dalam menyusun instrumen yang terlepas dari konsep padahal salah satu syarat instrumen soal KPS (Tahwil dan Liliasi, 2014) adalah tidak boleh terbebani konsep. Syarat ini penting terpenuhi untuk membedakan soal KPS dengan soal kognitif. Selain tidak terpenuhinya semua syarat soal KPS, peserta juga kurang terampil dalam menyusun kriteria rubrik penilaian yang logis menunjukkan gradasi mutu jawaban. Popham (1994) menjelaskan rubrik penilaian harus menunjukkan gradasi mutu jawaban yang tegas antar skornya. Kemampuan menyusun rubrik ini memang cukup sulit bagi pendidik yang terbiasa menyusun soal pilihan ganda. Kurniawan (2016) menemukan beberapa faktor yang menjadi kesulitan bagi guru dalam mengimplementasikan KPS salah satu yang paling dominan adalah kemampuan dalam menyusun instrumen penilaian.

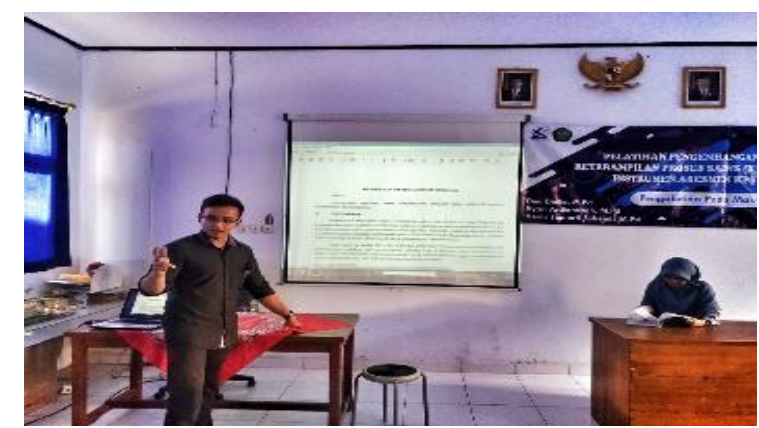

Gambar 2. Penyampaian materi LKPD KPS
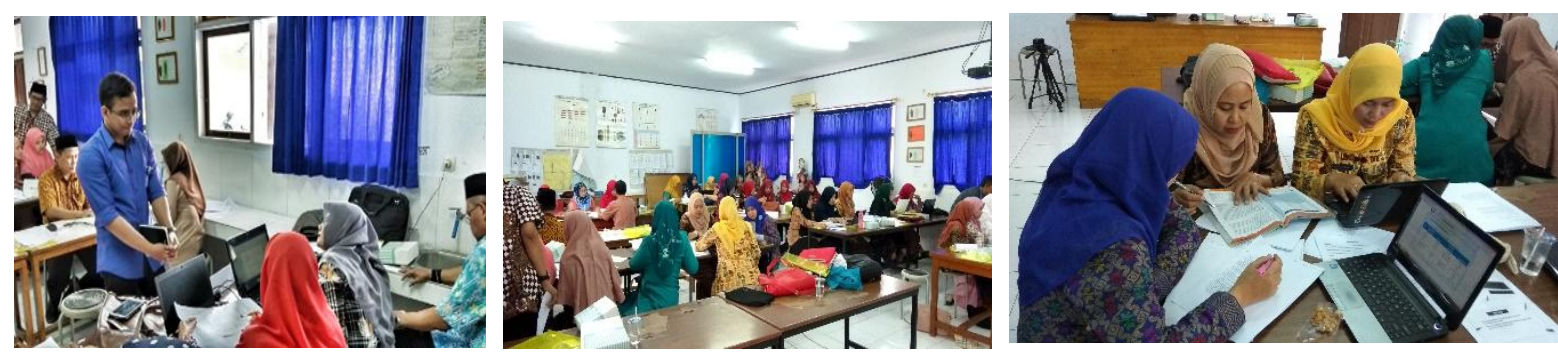

Gambar 3. Proses workshop 


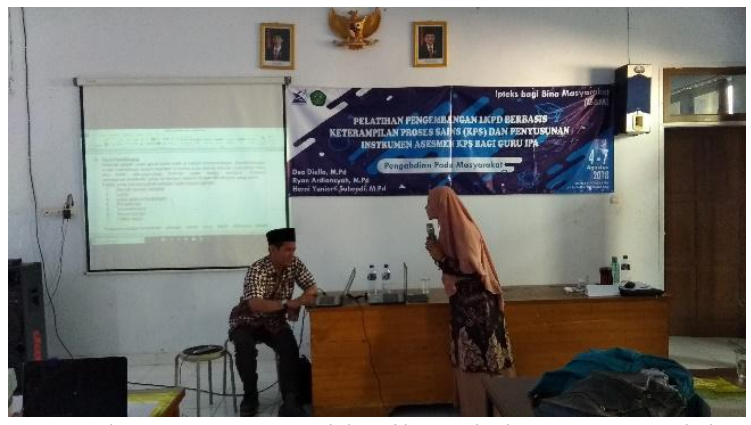

Gambar 4. Presentasi hasil workshop LKPD oleh peserta

Dampak kegiatan bagi guru yang menjadi peserta dapat diindikasikan dari kemampuannya dalam menyusun LKPD dan instrumen KPS. Guru memiliki wawasan lebih mendalam tentang implementasi pendekatan saintifik melalui pengembangan keterampilan proses sains. Selain itu guru juga menjadi termotivasi untuk menyusun LKPD sendiri agar dapat mengintegrasikan KPS dalam setiap pertemuan. Motivasi ini diprediksikan sebagai hasil dari pemberian feedback yang diberikan tim pemateri selama workshop dan feedback yang diberikan peer (rekan sesama partisipan) selama proses presentasi hasil. Sesuai dengan temuan Wigfield et al (2008) bahwa feedback dapat mempertahankan motivasi peserta didik selama proses belajar. Feedback yang diberikan selama workshop disajikan dalam bentuk "correct-incorrect" untuk menegaskan bagian LKPD KPS dan instrument KPS yang sudah tepat dan mana yang harus diperbaiki. Menurut Hattie dan Timperley (2007) bentuk feedback yang demikian memiliki effect size dalam kategori kecil yakni $0,25-0,43$. Maka tidak dipungkiri bentuk feedback yang demikian tidak begitu besar dampaknya untuk pemahaman guru IPA dalam menyusun instrumen KPS yang cukup kompleks karena memiliki syarat-syarat khusus. Selama kegiatan guru menyusun LKPD dan instrumen KPS secara berkelompok, kerjasama tersebut memberikan implikasi terhadap meningkatnya pemahaman guru dalam menyusus kedua perangkat belajar tersebut. Temuan tersebut relevan dengan yang disampaikan oleh Ariani (2018) yang menemukan efek kerjasam guru dalam kegiatan lesson study untuk penyusunan perangkat belajar. Dengan demikian metode workshop, dimana di dalamnya terdapat kegiatan pendampingan, pelatihan, pemberian umpan balik (feedback) dan kerjasama cukup mampu membantu guru IPA untuk memahami KPS dan mengintegrasikannya ke dalam LKPD dan instrument asesmen.

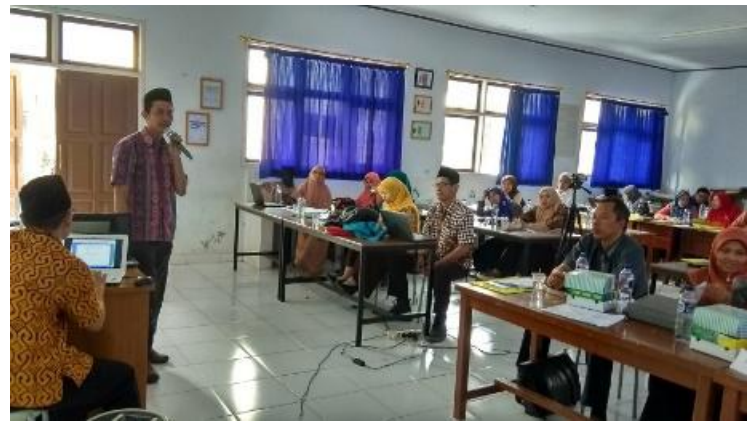

Gambar 5. Presentasi hasil workshop instrumen KPS oleh peserta

\section{KESIMPULAN \& SARAN}

Kegiatan yang sudah dilaksanakan oleh Tim Pengabdian Kepada Masyarakat dengan kegiatan Pengembangan LKPD berbasis Keterampilan Proses Sains dan Penyusunan Instrumen Asesmen KPS bagi Guru IPA memberikan manfaat bagi guru IPA dalam mengembangakan perangkat pembelajaran. Hasil workshop menunjukkan guru IPA sudah cukup mampu mengintegrasikan KPS dalam LKPD. Namun kemampuannya dalam menyusun instrumen asesmen KPS tidak sebaik kemampuan menyusun LKPD KPS. Umumnya mereka kesulitan dalam menyusun instrumen yang terlepas dari konsep (masih dibebani konsep) dan kurang mampu meyusun rubrik penilaian

Kegiatan pelatihan penyusunan LKPD dan asesmen sebaiknya dilakukan secara berkala untuk memperbaharui pengetahuan guru seiring perubahan kurikulum. Pelatihan penyusunan LKPD dapat dilakukan dengan mengintegrasikan keterampilan berpikir saintifik lainnya seperti literasi sains dan keterampilan generik sains dan menyusun instrumen asesmen yang relevan dengan keterampilan abad 21.

\section{DAFTAR PUSTAKA}

Anderson et al. (2010). Kerangka Landasan untuk Pembelajaran, Pengajaran, dan Asesmen. Yogyakarta: Pustaka Pelajar

Ariani, D.S. (2018). Pendampingan Lesson Study Untuk Meningkatkan Kompetensi Guru Sekolah Dasar di KKG Gugus Sungai Miai Banjarmasin dalam Menerapkan Pendekatan Saintifik Menggunakan Kurikulum 2013. Jurnal Publikasi Pendidikan Vol 8 (2) 2018

Gultepe, N. (2016). High School Science Teachers' Views on Science Process Skill. International Journal of Environmental \& Science Education 11 (5), 779-800 
Hattie,J and Timperley,H. (2007). The Power of Feedback. Review of Educational Research Vol.77,No 1,pp.81-112

Kurniawan,A dan Fadloli. (2016). Profil Penguasaan Keterampilan Proses Sains Mahasiswa. Proceeding Biology Education Conference. Vol 13(1) 2016: 410-419

Popham,W.J. (1994). Classroom Assessment: What Teachers Need to Know Sixth Edition. Boston : Pearson

Program Pendidikan Guru Sekolah Dasar Universitas Terbuka

Menteri Pendidikan dan Kebudayaan.(2016). Permendikbud Nomor 22 Tahun 2016 tentang Standar Proses Pendidikan Dasar dan Menengah. Jakarta

Tawil, Muh dan Liliasari (2014). Berpikir Kompleks dan Implementasinya dalam pembelajaran IPA. Makasar: Badan Penerbit UNM

Tawil, Muh dan Lilisari (2014). KeterampilanKeterampilan Sains dan Implementasinya dalam Pembelajaran IPA. Makasar: Badan Penerbit UNM

OECD.(2015). PISA 2015 Result : Excelent and Equity in Education. Paris: OECD Publishing

Wigfield, A., Klauda, S.L., \& Cambria, J. (2008). Influences on the development of academic self-regulatory processes. In B.J. Zimmerman, \& D. H. Schunk (Eds.), Handbook of selfregulation of learning and performance (pp.33-48). New York: Routledge. 